\title{
Perception Fishermen Community about the Importance of 12 Years of Formal Education
}

\author{
Bayu Indra Permana ${ }^{1, a^{*}}$, Agus Mursidi 2, b \\ ${ }^{1}$ Pancasila Education Study Program and Citizenship FKIP University PGRI of Banyuwangi East Java Indonesia \\ 2 Department of History Education FKIP University PGRI Banyuwangi East Java Indosesia \\ a bayuindraper@gmail.com, b agusmursidi78@gmail.com \\ ${ }^{*}$ Corresponding Author \\ Whatsapp number: [082334660992]
}

How to Cite : Permana, B., I., Mursidi, A. (2020). Perception Fishermen Community about the Importance of 12 Years of Formal Education. International Journal for Educational and Vocational Studies, 2 (1), 32-36. DOI: https://doi.org/10.29103/ijevs.v2i1.1888

\section{ARTICLE HISTORY}

Received:18 October 2019

Revised: 14 December 2019

Accepted: 22 January 2020

\section{KEYWORDS}

Fishermen

Comuunity

Education

Perception

\section{ABSTRACT}

This study aims to determine how people's perceptions fishermen about the importance of 12 years formal education and how the implications of the fishing community's perception of the importance of 12 years formal education. This research use desciptive qualitative approach. The sampling technique uses purposive sampling and snowball sampling and the data collection techniques used are documentation, semi-structured interviews and observation. Field data findings show that the fishing community in Kedungrejo Village is a heterogeneous, consumptive community and based on interviews found that community perceptions about the importance of 12 years of formal education are as a provision for diplomas to look for work as land laborers. The meaning of 12 years of formal education in the form of maturity has not yet been felt by the community from the number due to environmental and social factors which are seen from the number of 2292 elementary school students who continue to the first level only $30 \%$ ie 308 who reached the top education level. so the 12-year formal education function that has a role to develop the community's potential is indisputable because of the social stratum between the skipper fisherman and the fisherman laborers. It is here that the important function of 12 years formal education is completely collided with the perception of the fishing community in Kedungrejo Village, Muncar District.

This is an open access article under the CC-BY-SA license.

\section{INTRODUCTION}

Education is a systematic, planned effort in the process of fostering and learning consciously for individuals to grow and develop into independent, sovereign, independent, responsible people who are able to play their role as khalifah in the world and as God's creatures. As the purpose of education in Law Number 20 Year 2003 concerning the National Education System Article 3, "The purpose of national education is to develop the potential of students to become human beings of faith and to devote to God Almighty, to have noble, healthy, knowledgeable, capable, creative, creative, independent and become citizens of a democratic and responsible ". It can be interpreted here that education does not necessarily become a productive machine that prints people to meet the demands of the economic market.

Formal education (school) is one of the educational systems to create educated people regardless of the cultural background and economic level of the students involved in it (Kompri, 2015: 23). The education unit consists of basic education, secondary education and higher education. Basic education is the level of education that underlies the level of secondary education. The form of the basic education unit consists of Elementary Schools (SD) and Madrasah Ibtidaiyah (MI) which organize 6-year educational programs. Furthermore, junior high schools (SMP) or other forms of equals that hold a 3-year educational program. Continued High School (high school/high school/vocational school) or 13 other forms of the equivalent that hold a 3-year educational program (Mursidi: 2019). As well as higher education which includes Diploma, Bachelor, Specialist, and Doctoral degrees held by Higher Education.

Educational statistics data on the implementation of education that developed in the village of Kedungrejo shows that the children who carried out education were 2292 elementary school students and 549 who were carrying out secondary education while those attending high school were only 308 students. ). While the successful 
implementation of education is influenced by three factors, namely the responsibilities of parents, teachers and the community. Parents play a role in educating the family environment and teachers in the school environment (Mursidi: 2018). And the community has an influence that has a major influence on the ongoing educational process in an educational institution (Mursidi: 2018). schools that can survive and develop show a high level of participation and awareness of the importance of education, while the views of the community are inseparable from the cultural, social, religious, economic and educational influences that the community has (Mursidi: 2019). From these factors, it can be seen the complexity faced by education. one of them is the problem of education in Kedungrejo Village, Muncar District, Banyuwangi Regency.

The wealth of the Muncar marine product received the title as the second largest fish producer after Si Api-Api Riau, which caused the Muncar coastal fishermen to depend their lives on seafood (suryo: 2017). This causes an unstable economic situation due to the existence of the Padang Bulan season (full moon period) so that fishermen do not go to sea and there is a famine or what is familiarly called Laeb by the fishing community. That condition causes the assumption that education is an expensive thing.

The perception of the fishing community about the importance of 12 years of formal education is basically still limited to theoretical studies, either in the form of theses or books. But in fact from various studies there are many different points of view about the perception of fishing communities about the importance of 12 years formal education. Among them, Sriyanti Ninik (2006) and Kadriani La Harudu (2017) who examined the importance of formal education and the absence of formal education levels, both examined the involvement of parents in their children's education which was used as their perception. And the thesis of Makhsus (2013) fishermen's perception of the importance of formal education is shown by the percentage of positive and negative perceptions of the involvement of parents and children in the world of formal education 12 years.

Based on the above background, the problems that will be examined in this study are: 1 . What is the perception of the fishing community about the importance of 12-year formal education in Kedungrejo Village, Muncar District? 2 What are the implications of the perception of the fishing community about the importance of 12 years of formal education in Kedungrejo Village, Muncar District?

\section{METHODS}

Method used by researchers is a qualitative research method. The object of this research is the fishing community in Kedungrejo Village, Muncar District, Banyuwangi Regency.

Determination of the sample in this study was done by selecting a sample with certain considerations called purposive sampling. According to Sugiyono (2017, 94-95) purposive sampling is sampling data sources with certain considerations. The consideration is for example that person is considered to know best about what we expect to answer questions in the formulation of the problem, or maybe he is a ruler so that it makes it easier for researchers to explore the object/social situation under study. Snowball samplingsampling is a data sourcetechnique, which initially is small in number, gradually becomes large. This is done because of the small number of data sources that have not been able to provide satisfactory data, so look for other people who can be used as data sources (Sugiyono, 2014: 54).

The samples determined by the researchers are: 1 . Mr. Imam Rudianto as PJ Head of Kedungrejo Village to get data on the role of the government in encouraging the community about the importance of education. 2. $\mathrm{Mr}$. Ahmadi as a community leader to get data on community perceptions about education. 3. The coastal fishing community of Muncar Kedungrejo Village, namely the husband and wife of fishermen, the community's perception of the importance of education. Data collection techniques used by researchers are documentation, interviews and observations. Documentation namely data from government offices, newspapers, websites, etc. Observations made by researchers are observations of participants, where researchers are involved and come directly in the midst of respondents' activities. And interviews are conducted directly where researchers

face to face with the subject with a semi-structured interview technique. Data analysis technique used in this research is descriptive qualitative data analysis technique, which is data collection in the form of words not numbers. With the aim of describing the situation in the field (results research) and comparing it with an existing theory.

Checking the validity of the data is a test of trust in the data obtained in the field, both data based on interviews, documentation and observation. This aims to test the truth of data or information obtained. In qualitative research can be done by Triangulation.

Researchers use the technique Triangulation, which is meant for example the data obtained by the results of interviews and then checked with observation and documentation. If the three data credibility testing techniques produce different data, the researcher conducts further discussions with the data source to ascertain which data is the most correct. Or maybe it's all true with different points of view.

\section{RESULTS AND DISCUSSION}

The results obtained by researchers that the fishing community in the Village of Kedungrejo depended on their lives to catch the sea. Income derived from fishing is uncertain in nature. They surrendered their fate to the beauty of nature to earn a living and live a life. Some literature states that fishermen are a group of people classified as poor. When compared with other community groups in the agricultural sector, fishermen (especially 
laborers and traditional fishermen) can be classified as the poorest social strata, although it cannot be said that all fishermen are poor (Imron, 2003: 2).

In the socio-cultural dimension, poverty that binds fishermen cannot be counted in numbers, but it appears in the symptoms in the form of a culture of poverty. Lewis in (Imron 2003: 5) states that there are certain responses made by the poor in addressing life, such as wasteful in spending money, easy to despair, feeling helpless and apathetic. This condition is also experienced by the fishing community in Kedungrejo Village. In general, rich fishing communities (skipper) have a consumptive habit that is with an income above the average but they spend all that is deemed necessary it should not be a basic need (village head interview: 2019). In this case what becomes unnatural is when poor fishermen (fishing laborers) with low incomes are less than 2,000,000. per month have such a lifestyle, they immediately spend all the money captured. If fishermen have no catch and do not have savings savings, it is very regrettable if they have to sell their items such as household furniture or jewelry to meet their daily needs (interview, Kelapa Desa: 2019).

High expectations for fishing families so that they can overcome the economic problems they face are evident in the attitudes and what they tell. Likewise, it can be seen from the hopes of the fishing community to the government to free their children's education costs. If other people such as researchers visit, surely they ask "this is being asked, if the data is collected can help" and contains elements of complaints and criticism to the government to eliminate the cost of education for their children. If other people, such as researchers, visit them, surely they ask "this is being asked whether the data was collected for assistance" and contains complaints and criticisms to the government that social assistance both cash and non-cash provided previously is not on target or uneven. His expectation and judgment that he is eligible to receive cash and non-cash assistance is due to the same background, namely fishermen with uncertain income.

For the coastal fishing community of Muncar in Kedungrejo Village, which has always worked as a fisherman, the primary need is health. Work as a fisherman is just a menial job that requires energy and muscle and put aside their level of education, no matter how high their education will not affect the outcome of fishing. Every day fishermen work to use marine resources except when the fish are not in the light of the moon (the moon field) or in the famine season to meet their needs. And when they are healthy they will be able to do that. The low education of a fisherman will affect their skills, mindset and mentality.

To see how much responsibility fishermen have for their children and wives, fishermen earn a living for family needs and prepare children for their future (sugito interview with community leaders: 2019). It is expected that children can grow and develop as the foundation of parents in old age and the successor to the ideals of the nation's struggle. But what researchers get when in the field there are parents who have a lot of money but their children do not want to go to school and vice versa parents always try to how the child can be as high as possible. The cultural factor that develops in the community is that school is not a promising thing to make life better because there are also schools but it also goes to sea.

According to Ikhsan (Kadriani 2017: 3) education is a human activity and effort to improve his personality. Almost all people are subjected to education and carry out education because education is never separated from human life. In general, the perception of fishing families regarding the importance of 12 years of formal education is to provide children in the future with the hope of getting decent work and earning a better living than their parents' conditions. The harshness of life is illustrated because the work of fishermen is work that is close to death because of wrestling with the vast ocean, the magnitude of the waves and the unpredictable natural situation. The experience of parents who mengambarka helplessness as a fisherman does not want to be felt by their children.

The development of the perception of the Muncar coastal fishing community about the importance of 12 -year formal education is a diploma to get the ease of finding work as a land laborer. So the paradigm that develops in the community that 12 years of formal education does not really affect the children of fishermen, especially women, which happens that a girl with 12 years of formal education if married does not continue her career, women only become housewives with the domestic realm that is well kitchen and mattress. Even though what happens to parents, the fisherman's wife will later help earn a living if the sea products are deemed insufficient.

The nature of education revealed by Prof. Zahara Idris (basics of education): education is a series of communication activities between ordinary people (educators) and the students face to face directly or by using the media in order to provide assistance to the development of the child as a whole, in order to develop the potential in the form of physical, emotional, attitude, moral knowledge and skills as much as possible, in order to become a responsible adult human being.

The results of interviews with the fishing community in Kedungrejo Village that 12 years of formal education have not been able to mature the mindset and develop the potential of him and the fishing community in Kedungrejo Village in general. This is influenced by ethnic diversity, social environment, culture or culture in the face of globalization. The harshness of a fisherman's life and the tendency of a fisherman's child to gather in an association that has not been accompanied by coaching causes a 12-year formal education function not yet apparent to the formation of one's maturity. There is a cultural factor that 12 years of formal education is only able to take the child to be a worker or laborer on land and the child of the capital owner or entrepreneur will continue the economic wheel for fishermen. Such conditions illustrate the nature of 12 years 
of formal education in the development of the coastal fishing community of Muncar in Kedungrejo Village, unlike the concept of proper education.

There is an assumption that 12 years of formal education is important for the future or vice versa, because education does not promise the formation of personality. 12 years of formal education as an attempt to succeed children find work and they consider education only the impact of the current reality. Those who assume that 12 years of formal education have not been able to shape the personality and develop the potential of children because so far they see the output finalof education is in the form of a diploma to find work, the results of education in the form of attitude and personality formation have not been felt. Therefore the role of parents is very important to instill educational values for their children through family education and formal education in schools. With this education, children are expected to be free from ignorance and then become knowledgeable human beings for future provision and noble and skilled personalities.

\section{CONCLUSION}

Research conducted on Fishermen Community Perception about the importance of 12 years of formal education in Kedungrejo Village, Muncar District, Banyuwangi District based on the data obtained can be concluded that a person's income is uncertain depending on the number of catches. The division of catches consists of a system that is a system for dividing the moon (bright moon) and directly dividing bydivision fifty-fifty. The perception of the coastal fishing community of Muncar in Kedungrejo Village about the importance of formal education is illustrated that 12 years of formal education can succeed the fishermen's children in the future. The importance of 12 years of formal education is a diploma as an ease to find work as a laborer on land. Muncar coastal fishing community in Kedungrejo Village considers that 12 years of formal education has not been able to mature one's mindset. Due to several factors namely ethnic diversity in the Village of Kedungrejo, the pattern of life of fishermen the conditions for negative habits are njamu, consumptive, entrenched rah-rah, the tendency of fishing children to gather in associations without any guidance and direction to move forward, globalization and free flow association.

The social layer between the skipper fishermen and labor fishermen also affects the perception of the coastal fishing community of Muncar in Kedungerjo Village that formal education 12 has not been able to develop the potential of the fishing community. The potential that is owned by the fishing community in the Village of Kedungrejo is only able to be managed and developed by the capital owner and someone who is armed with 12 years of formal education will become a laborer.

\section{Acknowledgements}

Thank you: we thank the Faculty of Teacher Training and Education at the University of PGRI Banyuwangi and the review team Mr. Prof. Dr Miftahul Arifin M.Pd and Ms. Harwanti Noviandari M.Psi who provided questions and input for the completion of the study.

\section{REFERENCES}

BPS. (2017). Kecamatan Muncar Kabupaten Banyuwangi.

Imron, Masyhuri. (2003). Kemiskinan dalam Masyarakat Nelayan. Jurnal Masyarakat dan Budaya, 5(1), 63 -82.

Kadriani, Harudu La. (2017). Persepsi Masyarakat Nelayan Tentang Pentingnya Pendidikan Formal Di Desa Jawi-Jawi Kecamatan Bungku Selatan Kabupaten Morowali. Jurnal penelitian pendidikan Geografi, 1 (1), 1-16.

Kompri. (2015). Manajemen Pendidikan. Yogyakarta: Ar-ruzz Media.

Kusnadi. (2006). Perempuan Pesisir. Yogyakarta: LKiS.

Kusnadi. (2007). Akar Kemiskinan Nelayan. Yogyakarta: LKiS.

Mudyaharjo, Redjo. (2001). Filsafat Ilmu Pendidikan. Bandung: Remaja Rosdakarya.

Mursidi, Agus, et.al. (2019). Commodification Education at Darussolah Senior High School on Singojuruh, Banyuwangi-East Java Province. International Journal for Educational and Vocational Studies, Vol. 1 No 5.

Mursidi, Agus, et.al. (2018). The Rise Ideology of Kiai at State Senior High School Darussholah Singojuruh. IOSR Journal Of Humanities And Social Science (IOSR-JHSS) Volume 23, Issue 2, Ver. 1

Peraturan Pemerintah Republik Indonesia Nomor 19 Tahun 2005 Tentang Standar Nasional Pendidikan. Online:

https://www.unm.ac.id/files/surat/pp-19-tahun-2005-ttg -snp.pdf. Diakses:: 17 Maret 2017.

Peraturan Pemerintah Republik Indonesia Nomor 55 Tahun 2007 Tentang Pendidikan Agama Dan Pendidikan Keagamaan. Online: http://kemenag.go.id/ file/dokumen/PP5507.pdf. Diakses: 13 Maret 2016.

Peraturan Menteri Pendidikan Nasional Nomor 16 Tahun 2007 Tanggal 4 Mei 2007 Standar Kualifikasi Akademik Dan Kompetensi Guru. http://vervalsp.data.kemdikbud.go.id/ prosespembelajaran/file/Permendiknas\%20No\%2016\%2 0Tahun\%202007.pdf. Diakses:: 17 Maret 2017

Siregar, S. Nina Salmaniah. (2016). Kesadaran Masyarakat Nelayan Terhadap Pendidikan Anak. Jurnal ilmu Pemerintahan dan Sosial Politik UMA, 4(1), $1-10$.

Sugiyono. (2017). Metode Penelitian Kualitatif. Bandung: Alfabeta.

Suryani Nani., dkk. (2004). Analisis Pendidikan Formal Anak pada Keluarga Nelayan di Desa Karangjaladri Kecamatan Paringi Kabupaten Ciamis Provinsi Jawa Barat. Buletin Ekonomi Perikanan, 5(2), 33-43. 


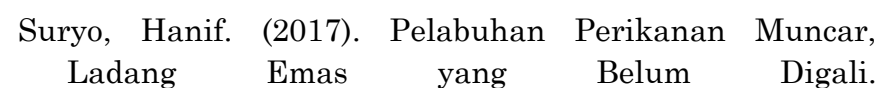
https://www.goodnewsfromindonesia.id/2017/01/17/pela buhan-perikanan-muncar-ladang-emas-yang-belum-dig ali.

Sriyanti, Ninik., dkk. (2006). "Persepsi Nelayan Tentang Pendidikan Formal di Kecamatan Rembang Kabupaten Rembang Provinsi Jawa Tengah". Buletin Ekonomi Perikanan, 4(3), 40-49.

Undang-Undang Republik Indonesia Nomor 20 Tahun 2003 Tentang Sistem Pendidikan Nasional. Online: http://pendis.kemenag.go.id/file/dokumen. Diakses: 25 November 2017.

Interview Mam Rudianto as the village chief of Kedungrejo Muncar Sugito as Community Leader. 